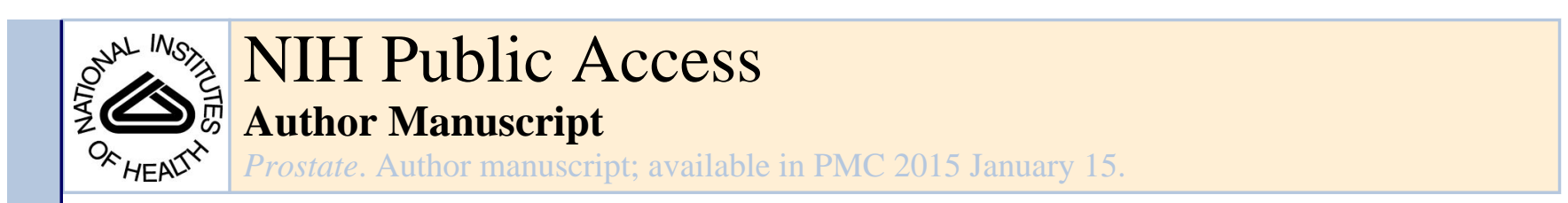

Published in final edited form as:

Prostate. 2011 July ; 71(10): 1033-1046. doi:10.1002/pros.21318.

\title{
5a-Reductase Type 3 Expression in Human Benign and Malignant Tissues: A Comparative Analysis During Prostate Cancer Progression
}

\author{
Alejandro Godoy ${ }^{1}$, Elzbieta Kawinski ${ }^{1}$, Yun Li ${ }^{1}$, Daizo Oka ${ }^{1}$, Borislav Alexiev ${ }^{2}$, Faris \\ Azzouni ${ }^{1}$, Mark A. Titus ${ }^{1}$, and James L. Mohler, MD ${ }^{1,3,4,5,{ }^{*}}$ \\ ${ }^{1}$ Department of Urology, Roswell Park Cancer Institute, Buffalo, New York 14263 \\ 2Department of Pathology, Roswell Park Cancer Institute, Buffalo, New York 14263 \\ ${ }^{3}$ Department of Urology, University at Buffalo School of Medicine and Biotechnology, Buffalo, \\ New York 14261 \\ ${ }^{4}$ Lineberger Comprehensive Cancer Center, University of North Carolina Schoolof Medicine, \\ Chapel Hill, North Carolina 27599 \\ ${ }^{5}$ Department of Surgery, Division of Urology, University of North Carolina School of Medicine, \\ Chapel Hill, North Carolina 27599
}

\section{Abstract}

BACKGROUND-A third isozyme of human 5a-steroid reductase, 5a-reductase-3, was identified in prostate tissue at the mRNA level. However, the levels of 5a-reductase-3 protein expression and its cellular localization in human tissues remain unknown.

METHODS-A specific monoclonal antibody was developed, validated, and used to characterize for the first time the expression of 5a-reductase-3 protein in 18 benign and 26 malignant human tissue types using immunostaining analyses.

RESULTS AND CONCLUSIONS-In benign tissues, 5a-reductase-3 immunostaining was high in conventional androgen-regulated human tissues, such as skeletal muscle and prostate. However, high levels of expression also were observed in non-conventional androgen-regulated tissues, which suggest either multiples target tissues for androgens or different functions of 5areductase- 3 among human tissues. In malignant tissues, $5 \mathrm{a}$-reductase- 3 immunostaining was ubiquitous but particularly over-expressed in some cancers compared to their benign counterparts, which suggests a potential role for 5a-reductase- 3 as a biomarker of malignancy. In benign prostate, 5a-reductase-3 immunostaining was localized to basal epithelial cells, with no immunostaining observed in secretory/luminal epithelial cells. In high-grade prostatic intraepithelial neoplasia (HGPIN), 5a-reductase-3 immunostaining was localized in both basal epithelial cells and neoplastic epithelial cells characteristic of HGPIN. In androgen-stimulated and

(C) 2010 Wiley-Liss, Inc.

"Correspondence to: James L. Mohler, MD, Associate Director for Translational Research and Chair, Department of Urology, Roswell Park Cancer Institute, Buffalo, New York 14263. james.mohler@ roswellpark.org.

Conflict of interest statement: The authors have no conflicts of interest. 
castration-recurrent prostate cancer $(\mathrm{CaP}), 5 \mathrm{a}$-reductase-3 immunostaining was present in most epithelial cells and at similar levels, and at levels higher than observed in benign prostate. Analyses of expression and functionality of 5a-reductase- 3 in human tissues may prove useful for development of treatment for benign prostatic enlargement and prevention and treatment of $\mathrm{CaP}$.

\section{Keywords}

5a-reductases; androgen metabolism; dihydrotestosterone; benign prostatic hyperplasia; castration-recurrent prostate cancer

\section{INTRODUCTION}

Androgen target cells use testosterone ( $\mathrm{T})$ as a prohormone, where $\mathrm{T}$ is converted by intracrine pathways into dihydrotestosterone (DHT), the most potent androgen receptor (AR) ligand. The enzyme steroid 5a-reductase (EC1.3.99.5) [1] localizes DHT biosynthesis to androgen responsive tissues. 5a-reductase isozymes 1 and 2 are well characterized [2] and DHT levels in target tissues are reduced using 5a-reductase inhibitors. However, male pattern baldness, that affects an estimated $70 \%$ of men by age 80 [3] responds poorly to $5 \mathrm{a}$ reductase-2 inhibition (finasteride, Propecia ${ }^{\mathrm{TM}}$ ) [4]. Lower urinary tract symptoms from benign prostate enlargement affect $50 \%$ of men age 50 or older [5], and $20 \%$ of men treated with the 5a-reductase-2 inhibitor, finasteride (Proscar ${ }^{\mathrm{TM}}$ ), or the bispecific inhibitor of 5areductase-1 and 2, dutasteride (Avodart ${ }^{\mathrm{TM}}$ ), require operative treatment within 4 years [6]. $\mathrm{CaP}$ is the most common non-skin cancer in American men; approximately 217730 Americans will be diagnosed with $\mathrm{CaP}$ and approximately 32050 men will die from $\mathrm{CaP}$ in 2010 [7]. Finasteride treatment of men at increased risk of $\mathrm{CaP}$ decreased the diagnosis of $\mathrm{CaP}$ by $25 \%$, however, the $\mathrm{CaP}$ that developed often was more poorly differentiated than observed in controls [8]. Dutasteride decreased the incidence of diagnosis of $\mathrm{CaP}$ and did not affect differentiation [9], but may cause delay of diagnosis that is concerning especially for aggressive $\mathrm{CaP}$ [10].

Men who fail curative therapy for clinically localized $\mathrm{CaP}$ or are diagnosed with advanced disease usually receive androgen deprivation therapy (ADT) that causes regression of androgen-stimulated $\mathrm{CaP}$ through programmed cell death [11]. However, ADT is palliative since $\mathrm{CaP}$ almost always recurs and causes death. A molecular role for $\mathrm{AR}$ in the transition from androgen-stimulated $\mathrm{CaP}$ to castration-recurrent $\mathrm{CaP}$ is supported by continuous expression of AR [12-14] and androgen-regulated genes [15]. Many alternative mechanisms allow AR-mediated transactivation of gene expression despite castrate levels of circulating testicular androgens (reviewed by Refs. 16-23). However, we and others have demonstrated that castration-recurrent $\mathrm{CaP}$ maintains tissue levels of DHT sufficient for activation of even wild-type AR [24-26]. Limited clinical experience has not demonstrated efficacy for finasteride added to ADT for advanced CaP [27] or for dutasteride or LY320236, another bispecific 5a-reductase inhibitor [28], for secondary treatment of castration-recurrent $\mathrm{CaP}$. Consequently, castration-recurrent $\mathrm{CaP}$ must be capable of biosynthesis of intraprostatic $\mathrm{T}$ from circulating adrenal androgens [29] or cholesterol [30] and metabolism of T to DHT at levels sufficient for AR activation by incompletely characterized mechanisms. 
Laboratory observations and clinical experience led to speculation about the existence of an additional 5a-reductase isozyme. A candidate sequence consistent with a 5a-reductase isozyme that mapped to chromosome 4q12 was identified by mining the Human Genome Project database [31]. Uemura et al. [32] confirmed the existence of a novel 5a-steroid reductase (SRD5A3, type-3) in human tissues but only at the mRNA level. Our study is the first to analyze the expression of 5a-reductase- 3 protein in human benign and malignant tissues. In this analysis, special emphasis was given to the expression of $5 \mathrm{a}$-reductase- 3 during prostate carcinogenesis and progression.

\section{MATERIALS AND METHODS}

\section{Cell Culture}

PWR-1E, a benign human prostate epithelial cell line, was purchased from American Type Culture Collection (ATCC, Manassas, VA) and maintained in Kerationocyte Serum Free media (Invitrogen, Carlsbad, CA) supplemented with $5 \mathrm{ng} / \mathrm{ml}$ recombinant EGF and 0.05 $\mathrm{mg} / \mathrm{ml}$ bovine pituitary extract (Gibco, Carlsbad, CA). LNCaP and C4-2 cells were maintained in RPMI-1640 supplemented with $2 \mathrm{mM}$ glutamine and $10 \%$ fetal bovine serum (FBS, Mediatech, Inc, Herndon, VA). LAPC-4 was maintained in RPMI-1640 supplemented with $10 \mathrm{nM}$ R1881 (Perkin-Elmer, Boston, MA). CWR-R1 was maintained in Richter's Improved MEM (Mediatech) supplemented with $20 \mathrm{mM}$ HEPES, $5 \mathrm{mg} / \mathrm{ml}$ insulin, $5 \mathrm{mg} / \mathrm{ml}$ transferin, $5 \mathrm{ng} / \mathrm{ml}$ sodium selenite (ITS, Roche, Indianapolis, IN), $0.1 \mathrm{mg} / \mathrm{ml}$ epidermal growth factor (Invitrogen), $1 \mathrm{mg} / \mathrm{ml}$ licoleic acid, $10 \mathrm{mM}$ nicotinamide (Sigma-Aldrich, St. Louis, MO), and 2\% FBS. CHO-K1, a subclone from the parental CHO cell line, was purchased from ATCC and maintained in Nutrient Mixture F12K Kaighn's modification media (Invitrogen) supplemented with $2 \mathrm{mM}_{\mathrm{L}}$-glutamine and 10\% FBS.

\section{Anti-5a-reductase-3 Polyclonaland Monoclonal Antibodies}

A commercially available polyclonal antibody produced by Sigma (SRD5A3, SigmaAldrich) and a total of four rabbit polyclonal antibodies produced commercially (Open Biosystems, Huntsville, AL) against amino acids 1-16, 3-18, 46-62, and 48-65 of the Nterminus of the 5a-reductase-3 protein were evaluated using Western blot and immunohistochemistry and the polyclonal antibody targeting the first epitope, $\mathrm{M}^{1}$ APWAEAEHSALNPLR ${ }^{16}$ performed best. Two hybridomas were produced in our laboratory against the same epitopes within the N-terminus and the RPCI-5aR3 monoclonal antibody performed best. RPCI-5aR3 antibody resulted from fusion of murine myeloma (P3X63 Ag8U.1, ATCC CRL 1597) with spleen cells of mouse hosts immunized with synthetic peptide ( $\mathrm{M}^{1}$ APWAEAEHSALNPLR ${ }^{16}$ ) using a standard procedure [33]. Each peptide was coupled to keyhole limpet hemocyanin using the 1-Ethyl-3-[3-

dimethylaminopropyl] carbodiimide hydrochloride method (Pierce). Hybridomas were cloned twice using the limiting dilution method [34]. Stable hybridomas that produced monoclonal antibodies were expanded and cryopreserved. Hybridoma cells were injected (1 $\times 10^{7}$ ) into the peritoneal cavity of female SCID mouse hosts to produce ascites fluid. All animal studies were performed in compliance with US Department of Health and Human Services Guide for the Care and Use of Laboratory Animals and approved by Roswell Park Cancer Institute Animal Care and Use Committee. Ascites fluid was harvested 3-4 weeks 
after hybridoma cells were injected when it contained $1.2-4 \mathrm{mg} / \mathrm{ml}$ of monoclonal antibody. Monoclonal antibodies were purified from ascites on Affi-gel protein A agarose (Bio-Rad) following manufacturers instructions. RPCI-5aR3 antibody was of the IgG-1 subclass, as determined using an ImmunoPure Monoclonal Antibody Isotyping Kit (Pierce). The immunoreactivity of the RPCI-5aR3 antibody with prostate cells was confirmed; crude extracts $(50 \mu \mathrm{g})$ prepared from LNCaP, C4-2, LAPC-4, and CWR-R1 cells were reacted with synthetic peptide $\left(20 \mathrm{ng}\right.$ ) at $4^{\circ} \mathrm{C}$ for $2 \mathrm{hr}$. The proteins were separated using SDS-Page and electrophoretically transferred onto a polyvinylidene fluoride membrane. Membranes were developed using the RPCI-5aR3 monoclonal or polyclonal antibodies, horseradish peroxidase (HRP), and electrochemoluminescence. The specificity of each antibody also was tested using an enzyme-linked immunosorbent assay (ELISA) and Western blot. The detection antigen was peptide conjugated with bovine serum albumin (BSA, EMD Chemicals, Gibbstown, NJ).

\section{Reverse Transcription and Quantitative Real-Time PCR}

Total RNA from CWR-R1 cells was isolated using RNeasy Mini kits (Qiagen). Total RNA (400 ng) was reverse-transcribed into cDNA using random primers (Invitrogen). Primers and probes for 5a-reductase-3 were purchased from Applied Biosystems. PCR reactions were performed using the 7300 Real-Time PCR system (Applied Biosystems) with a total reaction mixture volume of $25 \mu \mathrm{L}$ containing $8.0 \mathrm{ng}$ cDNA, $1 \times$ TaqMan Universal PCR Master Mix (Applied Biosystems) and 1× primers and probe mix. The PCR conditions for all reactions were: $95^{\circ} \mathrm{C}$ for $10 \mathrm{~min}, 40$ amplification cycles at $95^{\circ} \mathrm{C}$ for $15 \mathrm{sec}$ and $60^{\circ} \mathrm{C}$ for $1 \mathrm{~min}$. The relative mRNA levels of 5a-reductase-3 in LNCaP, C4-2, LAPC-4, and CWRR1 were expressed relative to PWR-1E.

\section{Western Blot}

Total cell extracts (50 $\mu \mathrm{g}$ of total protein) from PWR-1E, LNCaP, C4-2, LAPC-4, CWR-R1, and CHO-K1, were separated electrophoretically using SDS-poly-acrylamide gel electrophoresis (10\% w/v; Bio-Rad Laboratories, Hercules, CA) under reducing conditions and the separated proteins transferred to nitrocellulose membranes using standard procedures [35,36]. Western analyses utilized as primary antibody the RPCI-5aR3 $(1 \mu \mathrm{g} / \mathrm{ml})$ or the SRD5A3 (1 and $5 \mu \mathrm{g} / \mathrm{ml}$ ) antibody. HRP-conjugated anti-mouse or anti-rabbit IgG (Dako) was used as secondary antibody, respectively. Antibody localization was visualized using enhanced chemi-luminescence (Pierce Biotechnology). CHO-K1 cell line was used as negative control for expression of 5a-reductase-3 [37]. Equal loading of total cell extracts was verified visually by immunohistochemical staining of membranes with anti- $\beta$-actin (Santa Cruz Biotechnology).

\section{5a-Reductase-3 Immunostaining}

CWR-R1 cells were fixed in situ for $30 \mathrm{~min}$ at room temperature using $4 \% \mathrm{w} / \mathrm{v}$ paraformaldehyde. Endogenous peroxidase activity was inhibited with $3.0 \% \mathrm{v} / \mathrm{v}_{2} \mathrm{O}_{2}$ in methanol. Antibody specificity was evaluated by pre-incubating the monoclonal anti-body with the inhibitor peptide for $2 \mathrm{hr}$ before immunostaining. Tissue microarrays from benign and malignant human tissues were obtained from the Roswell Park Cancer Institute Department of Pathology. In addition, prostate tissue sections were cut from formalin-fixed, 
paraffin-embedded clinical specimens of androgen-stimulated benign prostate (BP) ( $n=8)$, high-grade prostatic intraepithelial neoplasia (HGPIN), $(n=8)$ and androgen-stimulated $\mathrm{CaP}$ $(n=8)$ obtained from the Department of Pathology archives or from a tissue microarray constructed from formalin-fixed, paraffin-embedded clinical specimens of androgenstimulated BP $(\mathrm{n}=18)$, androgen-stimulated $\mathrm{CaP}(\mathrm{n}=21)$ and castration-recurrent $(\mathrm{n}=19)$, $\mathrm{CaP}$ which has been studied previously [14,22,38-45]. All tissues and the images obtained from these tissues for analysis were reviewed by one pathologist (Borislav Alexiev). In tissue sections, antigens were retrieved using microwave irradiation and citrate buffer $\mathrm{pH}$ 6.0 for $15 \mathrm{~min}$. Endogenous peroxidase activity was inhibited using $3 \% \mathrm{v} / \mathrm{v} \mathrm{H}_{2} \mathrm{O}_{2}$ in methanol. Sections and CWR-R1 cells were incubated overnight with the RPCI-5aR3 antibody diluted 1:100 (optimum by checkerboard analysis of 1:50-1:1000 dilutions) in 100 $\mathrm{mM}$ Tris- $\mathrm{HCl}$ buffer ( $\mathrm{pH} 7.8$ ) that contained $8.4 \mathrm{mM}$ sodium phosphate, $3.5 \mathrm{mM}$ potassium phosphate, $120 \mathrm{mM} \mathrm{NaCl}$, and $1 \% \mathrm{w} / \mathrm{v} \mathrm{BSA}$. After washing 3 times for $10 \mathrm{~min}$ in Tris-HCl buffer (pH 7.8), sections were incubated with HRP-conjugated anti-mouse IgG (1/100, Dako, Carpinteria, CA) secondary antibody for $2 \mathrm{hr}$ at room temperature. Peroxidase activity was developed using $100 \mathrm{mM}$ Tris-HCl buffer containing 3,3-diaminobenzidine tetrahydrochloride $\left(1 \mu \mathrm{g} / \mathrm{ml}\right.$, Sigma-Aldrich) and $\mathrm{H}_{2} \mathrm{O}_{2}(1 \mu \mathrm{l} / \mathrm{ml}$, VWR International, West Chester, PA). Colocalization analyses of 5a-reductase-3/p63 and 5a-reductase-3/alphamethylacyl-coenzyme-A racemase (AMACR) were performed using the EnVision ${ }^{\mathrm{TM}} \mathrm{G} / 2$ Double Stain System according to the manufacturer's instructions (Dako) [46]. 5aReductase-3 was detected using an HRP-conjugated secondary antibody and 3,3diaminobenzidine tetrahydrochloride as substrate (brown precipitate) and p63 and AMACR protein expression were visualized using an alkaline phosphatase-conjugated secondary antibody and Permanent Red substrate (red precipitate). Sections were counterstained using hematoxylin. Immunohistochemistry in absence of primary antibody provided negative controls.

\section{Digital Image Collection and Analysis}

For cell lines and tissue sections (including tissue microarrays), images were collected using an Hamamatsu Color Chilled 3CCD camera (Hamamatsu, Bridgewater, NJ) mounted on an Axioskop microscope (Carl Zeiss, Thornwood, NY). For the prostate tissue microarray, five images were collected from each $2.0 \mathrm{~mm}$ core at total magnification 400x. The images were arranged in random order in a digital album using Adobe Photoshop (Adobe Systems, San Jose, CA) to facilitate visual scoring. Images were visually scored by three experienced observers (M. A. Titus, O. H. Ford and J. L. Mohler) who were blinded to tissue type. The observers scored the nuclear and cytoplasmic immunostaining on a scale ranging from 0 (no immunostaining) to 3 (strong immunostaining) in each of 100 nuclei or cells, respectively, to yield a visual score for each observor ranging from 0 to 300 for each feature in each specimen as described by Miyamoto et al. [47]. The intensity of cytoplasmic immunostaining also was assessed by quantitative image analysis using Image Pro Plus software (MediaCybernetics, Bethesda, MD). A circular region of fixed area was used to extract the intensity information for cytoplasmic immunostaining of all epithelial cells in each image scored visually. Mean optical density (MOD) was derived from mean intensity $\left(\mathrm{I}_{\mathrm{i}}\right)$ by setting the background intensity to white $\left(\mathrm{I}_{\mathrm{O}}=255\right)$ and using the equation [48]: 


$$
M O D=-\log \left(\frac{\mathrm{I}_{\mathrm{i}}}{\mathrm{I}_{\mathrm{o}}}\right)
$$

Mean visual scores and MOD were analyzed using Minitab (State College, PA). ANOVA (Tukey's honestly significant differences test) was used to compare visual scores of nuclear and cytoplasmic immunostaining and automated cytoplasmic immunostaining MOD [44]. Differences were considered statistically significant if $P<0.05$.

\section{RESULTS}

\section{Validation of the RPCI-5aR3 Monoclonal Antibody}

Expression of 5a-reductase-3 at the mRNA level was analyzed in the BP epithelial cell line PWR-1E and the androgen-sensitive CaP cell lines, LNCaP, and LAPC-4, and the castration-recurrent $\mathrm{CaP}$ cell lines, C4-2 and CWR-R1 (Fig. 1A). 5a-reductase-3 mRNA expression in androgen-stimulated $\mathrm{CaP}$ and castration-recurrent $\mathrm{CaP}$ cell lines were expressed relative to PWR-1E cell line, which expressed very low levels of 5a-reductase-3 mRNA as determined using standard PCR. High levels of 5a-reductase-3 mRNA expression compared to PWR-1E were observed in the LNCaP, LAPC-4, and CWR-R1 cell lines. However, the castration-recurrent C4-2 cell line showed 5a-reductase-3 mRNA levels comparable to the PWR-1E cell line. These results were confirmed at the protein level using western blot analysis and the RPCI-5aR3 antibody (Fig. 1B). A single band for 5areductase- 3 of in the range of 25-37 kDa was observed in total protein extracts of LAPC-4 and CWR-R1 cells (Fig. 1B), which corresponds to the expected size for 5a-reductase-3. However, no immuno-reactive band was observed in LNCaP cells, even though LNCaP expressed similar 5a-reductase-3 mRNA levels as LAPC-4 and CWR-R1. No immunoreactive band in the range of 25-37 kDa was observed in PWR-1E, C4-2, and CHOK1 cell lines (Fig. 1B). CWR-R1 cells were chosen to compare sensitivity of the RPCI-5aR3 and SDR5A3 (Sigma) antibodies. No immuno-reactive band in the range of 25$37 \mathrm{kDa}$ was detected using the SDR5A3 antibody, even when concentrations were 5-fold higher than suggested by the manufacturer (Fig. 1C). A weak band was appreciated using SDR5A3 antibody with longer times of exposure of the films (over $5 \mathrm{~min}$ ). Both antibodies (RPCI-5aR3 and SDR5A3) recognized a single band over $50 \mathrm{kDa}$, which does not correspond to the expected size for 5a-reductase-3 (data not shown). Sub-cellular localization of 5a-reductase- 3 protein and specificity of RPCI-5aR3 antibody were confirmed using immunostaining analyses. RPCI-5aR3 antibody showed a cytoplasmic immunostaining pattern (Fig. 1D); no nuclear immunostaining was observed. Incubation of RPCI-5aR3 antibody with the inhibitor peptide at increasing concentration ( 1 and $10 \mu \mathrm{g} / \mathrm{ml}$ ) for $2 \mathrm{hr}$ before immunostaining produced a peptide concentration-dependent inhibition of 5a-reductase-3 immunostaining in CWR-R1 cells (Fig. 1D). Complete inhibition of 5areductase-3 immunostaining was achieved at peptide concentration of $10 \mu \mathrm{g} / \mathrm{ml}$.

\section{5a-Reductase-3 Expression in Benign Human Tissues}

Semi-quantitative analysis of 5a-reductase-3 expression was performed in a panel of human benign tissues, which included androgen-responsive (liver $[n=20]$, skeletal muscle $[n=2]$, 
skin $[\mathrm{n}=1]$ testes $[\mathrm{n}=20]$, thyroid $[\mathrm{n}=20]$ ), and androgen-insensitive tissues (brain $[\mathrm{n}=$ 20], breast $[n=20]$, colon [ $n=20]$, endometrium [ $n=20]$, kidney [ $n=20]$, lung [ $n=20]$, myometrium [ $n=20]$, ovary [ $=20]$, pancreas $[n=15]$, spleen $[n=20]$, $[n=20]$, stomach $[\mathrm{n}=20]$, and tonsil [ $\mathrm{n}=15]$ ) (Figs. 2 and 3, Table I). High levels of 5a-reductase-3 protein expression were observed in a subset of human samples, which included skin (stratum basale and stratum spinosum), kidney (mostly proximal and some distal convoluted tubules), liver, skeletal muscle, myometrium, and pancreas (secretory epithelial cells). Moderate levels of expression of 5a-reductase-3 protein were observed in testis (Leydig cells), brain (neurons), breast (myoepithelial cells), colon (epithelial cells from colonic glands), and stomach (epithelial cells from the base of the gastric glands). Low levels of 5areductase-3 immunostaining were observed in lung (bronchial epithelium), and thyroid (cuboidal epithelium from thyroid follicles). 5a-reductase-3 was immunohistochemically undetectable in ovary, spleen, endometrium, and tonsil. In most cases, 5a-reductase-3 immunostaining was distributed homogeneously within the cytoplasm. However, perinuclear localization was observed when $5 a$-reductase- 3 immunostaining was intense. 5a-reductase-3 protein expression was observed both in conventional androgen-responsive benign tissues, such as skin and skeletal muscle, and non-conventional androgen-responsive tissues, such as kidney, colon and pancreas.

\section{5a-Reductase-3 Expressionin Malignant Human Tissues}

As was observed in benign tissues, 5a-reductase-3 immunostaining in malignant tissues showed inter-organ and inter-patient variability (Figs. 4 and 5, Table II). High levels of 5areductase-3 immunostaining were observed in malignant tissues from kidney (chromophobe carcinoma), liver (hepatocellular carcinoma), stomach (adenocarcinoma), thyroid (papillary carcinoma), colon (adenocarcinoma), and uterus (endometrioid adenocarcinoma). Moderate to low levels of 5a-reductase-3 immunostaining were observed in adrenal (pheochromocytoma), bladder (high grade urothelial carcinoma), breast (lobular and metaplastic carcinomas), esophagus (adenocarcinoma), kidney (clear cell renal cell carcinoma and papillary carcinoma), lung (adenocarcinoma), ovary (mucinous adenocarcinoma), testis (seminoma, embryonal and yolk sac carcinomas), and thyroid (medullary carcinoma). 5a-reductase-3 was immunocytochemically undetectable in bladder (low grade urothelial carcinoma and small cell carcinoma), lung (mesothelioma), leiomyosarcoma, and ovary (serous adenocarcinoma). 5a-reductase-3 immunostaining was confined to the cytoplasm of malignant epithelial cells, which exhibited perinuclear localization when intense. Among the malignant human tissues analyzed, only breast (lobular and metaplastic carcinomas), testis (seminoma, embryonal, and yolk sac carcinomas), lung (adenocarcinoma), and thyroid (papillary carcinoma) clearly showed over-expression of 5a-reductase-3 protein compared to their benign counterpart (compare Tables I and II). However, in the majority of cases, similar levels of 5a-reductase-3 immunostaining were observed between the benign and malignant tissue pairs (compare Tables I and II).

\section{5a-Reductase Expression During Carcinogenesis and Progression of Prostate Cancer}

5a-Reductase-3 immunostaining was analyzed in clinical specimens of different types of prostate tissues, since the prostate is a highly androgen-responsive organ (Fig. 6). In BP, 5a- 
reductase-3 immunostaining was observed primarily at the periphery of the benign glands, which suggests 5a-reductase- 3 expression in the basal cell compartment. This observation was confirmed by co-localization of 5a-reductase- 3 and p63, a basal cell marker. Low to undetectable levels of 5a-reductase-3 immunostaining were observed in luminal epithelial cells. In HGPIN, 5a-reductase-3 immunostaining localized to both basal cells and neoplastic luminal epithelial cells. However, 5a-reductase-3 was low in luminal epithelial cells of adjacent benign glands. In androgen-stimulated $\mathrm{CaP}$ and castration-recurrent $\mathrm{CaP}, 5 \mathrm{a}-$ reductase- 3 immunostaining was found in the cytoplasm of most malignant epithelial cells. $5 a-$-reductase- 3 immunostaining was mostly perinuclear when intense. Cytoplasmic 5areductase-3 immunostaining intensity was similar in androgen-stimulated $\mathrm{CaP}$ and castration-recurrent $\mathrm{CaP}$, and was higher than androgen-stimulated $\mathrm{BP}$, when compared using visual scores (ANOVA, $P<0.00001$ ) or image analysis (ANOVA, $P<0.00001$ ) (Table III). Nuclear immunostaining was minimal and varied marginally among androgenstimulated $\mathrm{BP}$, androgen-stimulated $\mathrm{CaP}$, and castration-recurrent $\mathrm{CaP}$ (ANOVA, $P=0.205$ ) (Table III). 5a-reductase-3 immunostaining in malignant epithelial cells was confirmed by co-localization of 5a-reductase-3 and AMACR immunostaining.

\section{DISCUSSION}

Several pieces of evidence suggested the presence of a third isozyme of 5a-reductase: a candidate gene sequence [31], low response rate of men with castration-recurrent $\mathrm{CaP}$ to dutasteride in a clinical trial [49], and failure of bi-specific 5a-reductase inhibitors to eliminate tissue levels of DHT (dutasteride reduced tissue levels of DHT by $94 \%$ in androgen-stimulated BP [50] and LY320236 failed to decrease serum DHT levels in intact men [51]). Uemura et al. [32] confirmed the existence of a novel 5 alpha-steroid reductase (SRD5A3, type-3) in human tissues but only at the mRNA level. They reported that 5areductase- 3 was overexpressed in castration-recurrent $\mathrm{CaP}$ cells. Gaining insight into the localization and function of 5a-reductase- 3 has proven difficult because commercially available antibodies against 5a-reductase- 3 became available only recently and characterizing 5a-reductase- 3 enzymatic activities is challenging, because the enzymes appear embedded within the endoplasmic reticulum, are hydrophobic, and form inclusion bodies when expressed in vitro. Our laboratory produced a highly specific monoclonal antibody (RPCI-5aR3) against the amino-terminal portion of the 5a-reductase- 3 protein and analyzed expression of this protein in benign and malignant human tissues, with special emphasis on prostate carcinogenesis and $\mathrm{CaP}$ progression. During the course of these studies, a commercially available polyclonal antibody against 5a-reductase-3 was released from Sigma. The Sigma antibody at concentrations that ranged from $1 \mu \mathrm{g} / \mathrm{ml}$ (concentration suggested by the manufacturer) to $5 \mu \mathrm{g} / \mathrm{ml}$ revealed no immuno-reactivity using western blot. The RPCI-5aR3 antibody, however, detected 5a-reductase-3 protein using immunocytochemistry, immunohistochemistry, and western blot. Further analyses are required to validate the RPCI-5aR3 antibody for ELISA and immunoprecipitation.

5a-Reductase-3 expression analyses in human tissues performed by Uemura et al. [32] were based on northern blot analysis. Their tissue expression analyses revealed very low levels of expression of 5a-reductase-3 mRNA in most benign adult organs, with benign pancreas showing the highest levels of expression of 5a-reductase- 3 mRNA. These results, however, 
contrast with the data reported by Yamana et al. [52] using QRT-PCR, which indicated a broader and higher expression of 5a-reductase-3 mRNA compared to 5a-reductase-1 and 2 mRNAs in human tissues. Our immunostaining analyses support Yamana's results and showed variable levels of expression of 5a-reductase-3 protein in several benign human tissues. The differences in expression of 5a-reductase-3 at the mRNA and protein levels between Uemura's study and our immunostaining analysis could be explained, at least in part, by differences in the sensitivity of the techniques utilized (northern blot versus immunostaining). Alternatively, presence of mRNA does not always correlate with expression of protein, as was demonstrated clearly in this study for 5a-reductase-3 expression in LNCaP cells, which highlights the importance of our immunostaining analysis.

5a-Reductase- 3 protein was expressed in both conventional androgen-regulated human tissues, such as skeletal muscle, skin, and prostate, and in non-conventional androgenregulated tissues, such as pancreas, colon, and kidney. These data suggest either multiple target tissues for androgens or different functions of 5a-reductase- 3 among benign human tissues. In support of the second hypothesis, Cantagrel et al. [53], reported that mutations in 5a-reductase-3 gene caused congenital disorders of glycosylation, which induce mental retardation and ophthalmologic and cerebellar defects. In this study, 5a-reductase- 3 protein was found necessary for the reduction of the a-isoprene unit of polyprenols to form dolichols, which are required for the $\mathrm{N}$-glycosylation process. Unpublished data from our laboratory using protein assays of recombinant 5a-reductase- 3 expressed in $\mathrm{CHO}$ cells and bacteria suggest conversion of $\mathrm{T}$, androstenedione, and progesterone to DHT, androstanedione, and 5a-pregnan-3-20-dione, respectively. Broad substrate specificity of this enzyme is consistent with ubiquitous expression of 5a-reductase-3 protein in human tissues.

In tumor tissues, 5a-reductase-3 protein expression was observed in several different types of malignancies. Among those tissues that expressed moderate to high levels of 5areductase- 3 , only cancers of breast, testis, lung, thyroid, and prostate showed overexpression of 5a-reductase-3 compared to their benign counterpart. Neither 5a-reductase-1 nor 5areductase- 2 has been advocated as a potential biomarker of malignancy. However, Uemura et al. [32] suggested over-expression of 5a-reductase-3 at the mRNA level in castrationrecurrent $\mathrm{CaP}$ compared to $\mathrm{BP}$. Even though the number of clinical specimens analyzed in this study is limited, these results warrant further investigation of a putative role for 5areductase- 3 as a biomarker of malignancy in the prostate, breast, testis, lung, and thyroid tissues.

Analysis of archival specimens suggested that 5a-reductase- 3 may provide a biomarker of malignancy in the prostate. 5a-reductase- 3 was expressed in the basal cells of androgenstimulated BP but was not detected in the benign luminal epithelium. In contrast, in CaP that lacks basal cells, 5a-reductase-3 was found in the malignant epithelium. HGPIN is hypothesized to be the precursor lesion for CaP [54]. In all six specimens of HGPIN examined, 5a-reductase- 3 was present in the basal cell layer of both benign glands and HGPIN, and although 5a-reductase-3 was not detected in luminal epithelial cells in benign glands adjacent to HGPIN lesions, 5a-reductase-3 was expressed in the neoplastic cells of HGPIN lesions. These findings suggest that a characteristic of the development of $\mathrm{CaP}$ may 
be the transition of 5a-reductase-3 expression from the basal cell compartment to the cancer epithelial cell compartment; maintenance of 5a-reductase- 3 expression may be a characteristic of progression.

We [44] and others [55] reported previously that 5a-reducing capacity shifted from 5areductase- 2 in androgen-stimulated $\mathrm{BP}$ to $5 \mathrm{a}$-reductase- 1 in androgen-stimulated $\mathrm{CaP}$ and castration-recurrent $\mathrm{CaP}$. However, some if not most, of the 5a-reducing capability of castration-recurrent $\mathrm{CaP}$ may be due to 5a-reductase-3. However, the presence of high levels of 5a-reductase-3 protein, and new knowledge gained of the potential importance of $5 a$-reduction in preclinical models of castration-recurrent $\mathrm{CaP}[29,30,56]$ suggest an important role for 5a-reductase-3 in the lethal phenotype of $\mathrm{CaP}$. The potential clinical importance of 5a-reductase- 3 in $\mathrm{CaP}$ requires further investigation but tri-specific $5 \mathrm{a}$ reductase- 3 inhibitors may prove useful for treatment of benign prostatic enlargement and prevention and treatment of $\mathrm{CaP}$, especially advanced $\mathrm{CaP}$. These common diseases all depend on tissue levels of DHT for AR transactivation that may persist in spite of currently available treatments due to unblocked 5a-reductase-3 activity.

\section{CONCLUSIONS}

The results of this study allow one to conclude that: (i) expression of 5a-reductase-3 in "classical" as well as "non-classical" androgen-regulated tissues is consistent with 5areductase- 3 enzyme having functions other than converting T to DHT in human tissues, such as participation in the $\mathrm{N}$-glycosylation process; (ii) over-expression of 5a-reductase-3 in breast, testis, lung, thyroid, and particularly prostate cancer, compared to their benign counterparts, suggests a potential role for 5a-reductase-3 as a biomarker of malignancy; and (iii) over-expression of 5a-reductase-3 in AS-CaP and CR-CaP suggests a potential role for this enzyme in synthesizing DHT in both an androgen-stimulated and an androgen-deprived human prostate microenvironment.

\section{ACKNOWLEDGMENTS}

The CaP cell lines LNCaP, LAPC-4, LNCaP-C4-2, and CWR-R1, were provided by Drs. Allen Gao, Charles Sawyers, and Christopher Gregory. The authors thank Carol Wrzosek for technical assistance. This work was supported by the National Cancer Institute at the National Institutes of Health PO1-CA77739 (J. L. Mohler), National Cancer Institute Cancer Center Support Grants CA016156 and CA034026 to Roswell Park Cancer Institute and University of North Carolina, respectively, and Department of Defense Grant W81XWH-08-1-0330 (A. Godoy).

\section{REFERENCES}

1. Labrie F. Intracrinology. Mol Cell Endocrinol. 1991; 78(3):C113-118. [PubMed: 1838082]

2. Russell DW, Wilson JD. Steroid 5 alpha-reductase: two genes/two enzymes. Annu Rev Biochem. 1994; 63:25-61. [PubMed: 7979239]

3. Hawk E, Breslow RA, Graubard BI. Male pattern baldness and clinical prostate cancer in the epidemiologic follow-up of the first National Health and Nutrition Examination Survey. Cancer Epidemiol Biomarkers Prev. 2000; 9(5):523-527. [PubMed: 10815699]

4. Olsen EA, Hordinsky M, Whiting D, Stough D, Hobbs S, Ellis ML, Wilson T, Rittmaster RS. The importance of dual 5alpha-reductase inhibition in the treatment of male pattern hair loss: Results of a randomized placebo-controlled study of dutasteride versus finasteride. J Am Acad Dermatol. 2006; 55(6):1014-1023. [PubMed: 17110217] 
5. Napalkov P, Maisonneuve P, Boyle P. Worldwide patterns of prevalence and mortality from benign prostatic hyperplasia. Urology. 1995; 46(3 Suppl A):41-46. [PubMed: 7544516]

6. Roehrborn CG, Marks LS, Fenter T, Freedman S, Tuttle J, Gittleman M, Morrill B, Wolford ET. Efficacy and safety of dutasteride in the four-year treatment of men with benign prostatic hyperplasia. Urology. 2004; 63(4):709-715. [PubMed: 15072886]

7. Jemal A, Siegel R, Xu J, Ward E. Cancer Statistics, 2010. CA Cancer J Clin. 2010; 60(5):277-300. [PubMed: 20610543]

8. Thompson IM, Goodman PJ, Tangen CM, Lucia MS, Miller GJ, Ford LG, Lieber MM, Cespedes RD, Atkins JN, Lippman SM, Carlin SM, Ryan A, Szczepanek CM, Crowley JJ, Coltman CA. The influence of finasteride on the development of prostate cancer. N Engl J Med. 2003; 349(3):215224. [PubMed: 12824459]

9. Andriole GL, Bostwick DG, Brawley OW, Gomella LG, Marberger M, Montorsi F, Pettaway CA, Tammela TL, Teloken C, Tindall DJ, Somerville MC, Wilson TH, Fowler IL, Rittmaster RS. Effect of dutasteride on the risk of prostate cancer. N Engl J Med. 2010; 362(13):1192-1202. [PubMed: 20357281]

10. Walsh PC. Chemoprevention of prostate cancer. N Engl J Med. 2010; 362(13):1237-1238. [PubMed: 20357287]

11. Denmeade SR, Lin XS, Isaacs JT. Role of programmed (apoptotic) cell death during the progression and therapy for prostate cancer. Prostate. 1996; 28(4):251-265. [PubMed: 8602401]

12. Culig Z, Hobisch A, Hittmair A, Peterziel H, Cato AC, Bartsch G, Klocker H. Expression, structure, and function of androgen receptor in advanced prostatic carcinoma. Prostate. 1998; 35(1):63-70. [PubMed: 9537601]

13. de Vere White R, Meyers F, Chi SG, Chamberlain S, Siders D, Lee F, Stewart S, Gumerlock PH. Human androgen receptor expression in prostate cancer following androgen ablation. Eur Urol. 1997; 31(1):1-6. [PubMed: 9032526]

14. Mohler JL, Gregory CW, Ford OH, Kim D, Weaver CM, Petrusz P, Wilson EM, French FS. The androgen axis in recurrent prostate cancer. Clin Cancer Res. 2004; 10(2):440-448. [PubMed: 14760063]

15. Mousses S, Wagner U, Chen Y, Kim JW, Bubendorf L, Bittner M, Pretlow T, Elkahloun AG, Trepel JB, Kallioniemi OP. Failure of hormone therapy in prostate cancer involves systematic restoration of androgen responsive genes and activation of rapamycin sensitive signaling. Oncogene. 2001; 20(46):6718-6723. [PubMed: 11709706]

16. Arnold JT, Isaacs JT. Mechanisms involved in the progression of androgen-independent prostate cancers: It is not only the cancer cell's fault. Endocr Relat Cancer. 2002; 9(1):61-73. [PubMed: 11914183]

17. Feldman BJ, Feldman D. The development of androgen-independent prostate cancer. Nat Rev Cancer. 2001; 1(1):34-45. [PubMed: 11900250]

18. Gelmann EP. Molecular biology of the androgen receptor. J Clin Oncol. 2002; 20(13):3001-3015. [PubMed: 12089231]

19. Agoulnik IU, Vaid A, Nakka M, Alvarado M, Bingman WE, Erdem H, Frolov A, Smith CL, Ayala GE, Ittmann MM, Weigel NL. Androgens modulate expression of transcription intermediary factor 2 , an androgen receptor coactivator whose expression level correlates with early biochemical recurrence in prostate cancer. Cancer Res. 2006; 66(21):10594-10602. [PubMed: 17079484]

20. Gregory CW, He B, Johnson RT, Ford OH, Mohler JL, French FS, Wilson EM. A mechanism for androgen receptor-mediated prostate cancer recurrence after androgen deprivation therapy. Cancer Res. 2001; 61(11):4315-4319. [PubMed: 11389051]

21. Guo Z, Dai B, Jiang T, Xu K, Xie Y, Kim O, Nesheiwat I, Kong X, Melamed J, Handratta VD, Njar VC, Brodie AM, Yu LR, Veenstra TD, Chen H, Qiu Y. Regulation of androgen receptor activity by tyrosine phosphorylation. Cancer Cell. 2006; 10(4):309-319. [PubMed: 17045208]

22. Mahajan NP, Liu Y, Majumder S, Warren MR, Parker CE, Mohler JL, Earp HS, Whang YE. Activated Cdc42-associated kinase Ack1 promotes prostate cancer progression via androgen receptor tyrosine phosphorylation. Proc Natl Acad Sci USA. 2007; 104(20):8438-8443. [PubMed: 17494760] 
23. Ponguta LA, Gregory CW, French FS, Wilson EM. Site-specific androgen receptor serine phosphorylation linked to epidermal growth factor-dependent growth of castration-recurrent prostate cancer. J Biol Chem. 2008; 283(30):20989-21001. [PubMed: 18511414]

24. Belanger B, Belanger A, Labrie F, Dupont A, Cusan L, Monfette G. Comparison of residual C-19 steroids in plasma and prostatic tissue of human, rat and guinea pig after castration: unique importance of extratesticular androgens in men. J Steroid Biochem. 1989; 32(5):695-698. [PubMed: 2525654]

25. Geller J, Albert J, Loza D. Steroid levels in cancer of the prostate-markers of tumour differentiation and adequacy of anti-androgen therapy. J Steroid Biochem. 1979; 11(1B):631-636. [PubMed: 491627]

26. Titus MA, Schell MJ, Lih FB, Tomer KB, Mohler JL. Testosterone and dihydrotestosterone tissue levels in recurrent prostate cancer. Clin Cancer Res. 2005; 11(13):4653-4657. [PubMed: 16000557]

27. Fleshner NE, Trachtenberg J. Combination finasteride and flutamide in advanced carcinoma of the prostate: Effective therapy with minimal side effects. J Urol. 1995; 154(5):1642-1645. discussion 1645-1646. [PubMed: 7563310]

28. Gregory CW, Fei X, Ponguta LA, He B, Bill HM, French FS, Wilson EM. Epidermal growth factor increases coactivation of the androgen receptor in recurrent prostate cancer. J Biol Chem. 2004; 279(8):7119-7130. [PubMed: 14662770]

29. Stanbrough M, Bubley GJ, Ross K, Golub TR, Rubin MA, Penning TM, Febbo PG, Balk SP. Increased expression of genes converting adrenal androgens to testosterone in androgenindependent prostate cancer. Cancer Res. 2006; 66(5):2815-2825. [PubMed: 16510604]

30. Locke JA, Guns ES, Lubik AA, Adomat HH, Hendy SC, Wood CA, Ettinger SL, Gleave ME, Nelson CC. Androgen levels increase by intratumoral de novo steroidogenesis during progression of castration-resistant prostate cancer. Cancer Res. 2008; 68(15):6407-6415. [PubMed: 18676866]

31. Ota T, Suzuki Y, Nishikawa T, Otsuki T, Sugiyama T, Irie R, Wakamatsu A, Hayashi K, Sato H, Nagai K, Kimura K, Makita H, Sekine M, Obayashi M, Nishi T, Shibahara T, Tanaka T, Ishii S, Yamamoto J, Saito K, Kawai Y, Isono Y, Nakamura Y, Nagahari K, Murakami K, Yasuda T, Iwayanagi T, Wagatsuma M, Shiratori A, Sudo H, Hosoiri T, Kaku Y, Kodaira H, Kondo H, Sugawara M, Takahashi M, Kanda K, Yokoi T, Furuya T, Kikkawa E, Omura Y, Abe K, Kamihara K, Katsuta N, Sato K, Tanikawa M, Yamazaki M, Ninomiya K, Ishibashi T, Yamashita H, Murakawa K, Fujimori K, Tanai H, Kimata M, Watanabe M, Hiraoka S, Chiba Y, Ishida S, Ono Y, Takiguchi S, Watanabe S, Yosida M, Hotuta T, Kusano J, Kanehori K, Takahashi-Fujii A, Hara H, Tanase TO, Nomura Y, Togiya S, Komai F, Hara R, Takeuchi K, Arita M, Imose N, Musashino K, Yuuki H, Oshima A, Sasaki N, Aotsuka S, Yoshikawa Y, Matsunawa H, Ichihara T, Shiohata N, Sano S, Moriya S, Momiyama H, Satoh N, Takami S, Terashima Y, Suzuki O, Nakagawa S, Senoh A, Mizoguchi H, Goto Y, Shimizu F, Wakebe H, Hishigaki H, Watanabe T, Sugiyama A, Takemoto M, Kawakami B, Yamazaki M, Watanabe K, Kumagai A, Itakura S, Fukuzumi Y, Fujimori Y, Komiyama M, Tashiro H, Tanigami A, Fujiwara T, Ono T, Yamada K, Fujii Y, Ozaki K, Hirao M, Ohmori Y, Kawabata A, Hikiji T, Kobatake N, Inagaki H, Ikema Y, Okamoto S, Okitani R, Kawakami T, Noguchi S, Itoh T, Shigeta K, Senba T, Matsumura K, Nakajima Y, Mizuno T, Morinaga M, Sasaki M, Togashi T, Oyama M, Hata H, Watanabe M, Komatsu T, Mizushima-Sugano J, Satoh T, Shirai Y, Takahashi Y, Nakagawa K, Okumura K, Nagase T, Nomura N, Kikuchi H, Masuho Y, Yamashita R, Nakai K, Yada T, Nakamura Y, Ohara $\mathrm{O}$, Isogai T, Sugano S. Complete sequencing and characterization of 21,243 full-length human cDNAs. Nat Genet. 2004; 36(1):40-45. [PubMed: 14702039]

32. Uemura M, Tamura K, Chung S, Honma S, Okuyama A, Nakamura Y, Nakagawa H. Novel 5 alpha-steroid reductase (SRD5A3, type-3) is overexpressed in hormone-refractory prostate cancer. Cancer Sci. 2008; 99(1):81-86. [PubMed: 17986282]

33. Kohler G, Milstein C. Continuous cultures of fused cells secreting antibody of predefined specificity. Nature. 1975; 256(5517):495-497. [PubMed: 1172191]

34. Coller HA, Coller BS. Statistical analysis of repetitive subcloning by the limiting dilution technique with a view toward ensuring hybridoma monoclonality. Hybridoma. 1983; 2(1):91-96. [PubMed: 6381288] 
35. Godoy A, Ormazabal V, Moraga-Cid G, Zuniga FA, Sotomayor P, Barra V, Vasquez O, Montecinos V, Mardones L, Guzman C, Villagran M, Aguayo LG, Onate SA, Reyes AM, Carcamo JG, Rivas CI, Vera JC. Mechanistic insights and functional determinants of the transport cycle of the ascorbic acid transporter SVCT2. Activation by sodium and absolute dependence on bivalent cations. J Biol Chem. 2007; 282(1):615-624. [PubMed: 17012227]

36. Godoy A, Watts A, Sotomayor P, Montecinos VP, Huss WJ, Onate SA, Smith GJ. Androgen receptor is causally involved in the homeostasis of the human prostate endothelial cell. Endocrinology. 2008; 149(6):2959-2969. [PubMed: 18292195]

37. Thigpen AE, Cala KM, Russell DW. Characterization of Chinese hamster ovary cell lines expressing human steroid 5 alpha-reductase isozymes. J Biol Chem. 1993; 268(23):17404-17412. [PubMed: 8394341]

38. Ford OH, Gregory CW, Kim D, Smitherman AB, Mohler JL. Androgen receptor gene amplification and protein expression in recurrent prostate cancer. J Urol. 2003; 170(5):1817-1821. [PubMed: 14532783]

39. Karpf AR, Bai S, James SR, Mohler JL, Wilson EM. Increased expression of androgen receptor coregulator MAGE-11 in prostate cancer by DNA hypomethylation and cyclic AMP. Mol Cancer Res. 2009; 7(4):523-535. [PubMed: 19372581]

40. Mahajan NP, Whang YE, Mohler JL, Earp HS. Activated tyrosine kinase Ack1 promotes prostate tumorigenesis: Role of Ack1 in polyubiquitination of tumor suppressor Wwox. Cancer Res. 2005; 65(22):10514-10523. [PubMed: 16288044]

41. Majumder S, Liu Y, Ford OH, Mohler JL, Whang YE. Involvement of arginine methyltransferase CARM1 in androgen receptor function and prostate cancer cell viability. Prostate. 2006; 66(12): 1292-1301. [PubMed: 16705743]

42. Singh SS, Qaqish B, Johnson JL, Ford OH, Foley JF, Maygarden SJ, Mohler JL. Sampling strategy for prostate tissue microarrays for Ki-67 and androgen receptor biomarkers. Anal Quant Cytol Histol. 2004; 26(4):194-200. [PubMed: 15457671]

43. Smitherman AB, Mohler JL, Maygarden SJ, Ornstein DK. Expression of annexin I, II and VII proteins in androgen stimulated and recurrent prostate cancer. J Urol. 2004; 171(2 Pt 1):916-920. [PubMed: 14713853]

44. Titus MA, Gregory CW, Ford OH, Schell MJ, Maygarden SJ, Mohler JL. Steroid 5alpha-reductase isozymes I and II in recurrent prostate cancer. Clin Cancer Res. 2005; 11(12):4365-4371. [PubMed: 15958619]

45. Titus MA, Tan JA, Gregory CW, Ford OH, Subramanian RR, Fu H, Wilson EM, Mohler JL, French FS. 14-3-3 eta\} Amplifies Androgen Receptor Actions in Prostate Cancer. Clin Cancer Res. 2009; 15(24):7571-7581. [PubMed: 19996220]

46. Sotomayor P, Godoy A, Smith GJ, Huss WJ. Oct4A is expressed by a subpopulation of prostate neuroendocrine cells. Prostate. 2009; 69(4):401-410. [PubMed: 19058139]

47. Miyamoto KK, McSherry SA, Dent GA, Sar M, Wilson EM, French FS, Sharief Y, Mohler JL. Immunohistochemistry of the androgen receptor in human benign and malignant prostate tissue. $\mathrm{J}$ Urol. 1993; 149(5):1015-1019. [PubMed: 7683339]

48. Singh SS, Kim D, Mohler JL. Java Web Start based software for automated quantitative nuclear analysis of prostate cancer and benign prostate hyperplasia. Biomed Eng Online. 2005; 4(1):31. [PubMed: 15888205]

49. Shah SK, Trump DL, Sartor O, Tan W, Wilding GE, Mohler JL. Phase II study of Dutasteride for recurrent prostate cancer during androgen deprivation therapy. J Urol. 2009; 181(2):621-626. [PubMed: 19091347]

50. Wurzel R, Ray P, Major-Walker K, Shannon J, Rittmaster R. The effect of dutasteride on intraprostatic dihydrotestosterone concentrations in men with benign prostatic hyperplasia. Prostate Cancer Prostatic Dis. 2007; 10(2):149-154. [PubMed: 17189955]

51. Eisenberger MA, Laufer M, Vogelzang NJ, Sartor O, Thornton D, Neubauer BL, Sinibaldi V, Lieskovsky G, Carducci MA, Zahurak M, Raghavan D. Phase I and clinical pharmacology of a type I and II, 5-alpha-reductase inhibitor (LY320236) in prostate cancer: Elevation of estradiol as possible mechanism of action. Urology. 2004; 63(1):114-119. [PubMed: 14751361] 
52. Yamana K, Labrie F, Luu-The V. Human type 3 5a-reductase is expressed in peripheral tissues at higher levels than type 1 and type 3 and its activity is potently inhibited by finasteride and dutasteride. Horm Mol Biol Clin Invest. 2010; 2(3):293-299.

53. Cantagrel V, Lefeber DJ, Ng BG, Guan Z, Silhavy JL, Bielas SL, Lehle L, Hombauer H, Adamowicz M, Swiezewska E, De Brouwer AP, Blumel P, Sykut-Cegielska J, Houliston S, Swistun D, Ali BR, Dobyns WB, Babovic-Vuksanovic D, van Bokhoven H, Wevers RA, Raetz CR, Freeze HH, Morava E, Al-Gazali L, Gleeson JG. SRD5A3 is required for converting polyprenol to dolichol and is mutated in a congenital glycosylation disorder. Cell. 2010; 142(2): 203-217. [PubMed: 20637498]

54. McNeal JE, Bostwick DG. Intraductal dysplasia: A premalignant lesion of the prostate. Hum Pathol. 1986; 17(1):64-71. [PubMed: 3943853]

55. Thomas LN, Lazier CB, Gupta R, Norman RW, Troyer DA, O’Brien SP, Rittmaster RS. Differential alterations in 5alpha-reductase type 1 and type 2 levels during development and progression of prostate cancer. Prostate. 2005; 63(3):231-239. [PubMed: 15538746]

56. Montgomery RB, Mostaghel EA, Vessella R, Hess DL, Kalhorn TF, Higano CS, True LD, Nelson PS. Maintenance of intratumoral androgens in metastatic prostate cancer: A mechanism for castration-resistant tumor growth. Cancer Res. 2008; 68(11):4447-4454. [PubMed: 18519708] 
A

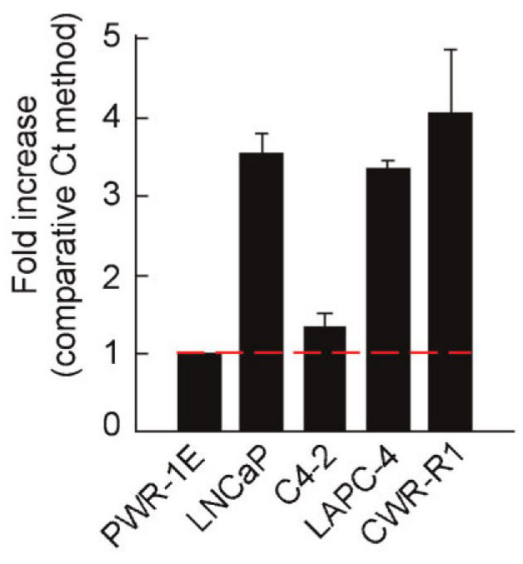

B
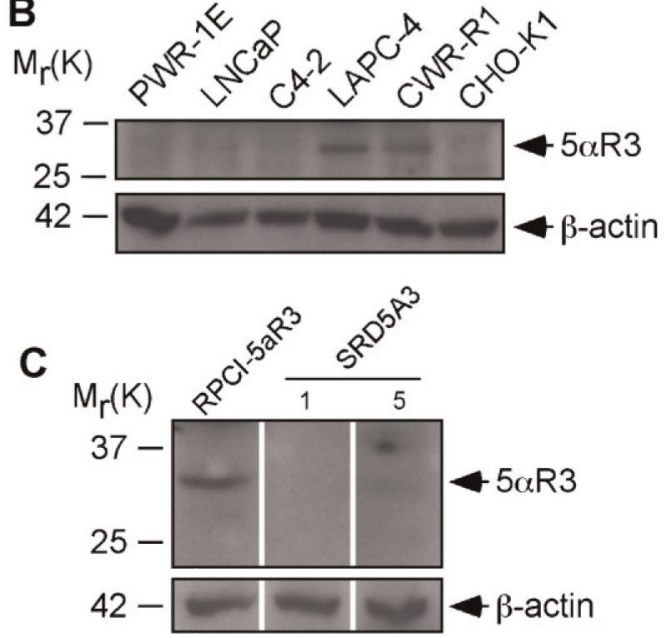

D

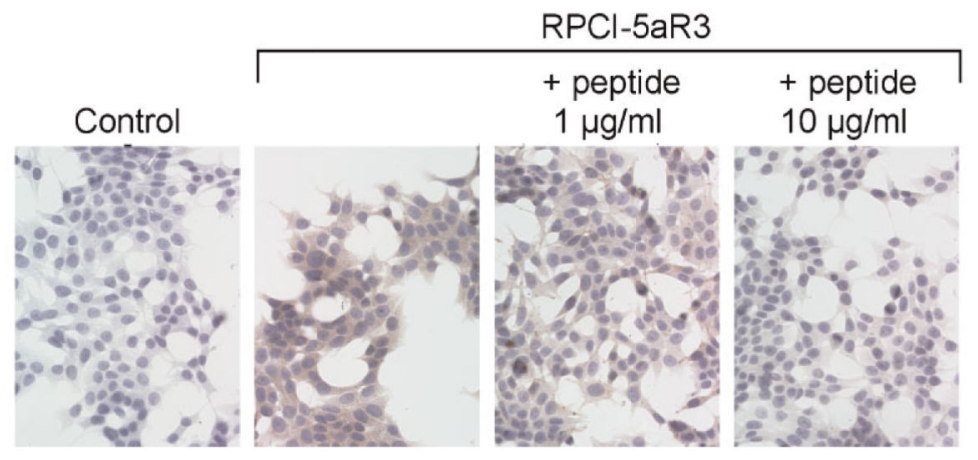

Fig. 1.

Validation of the RPCI-5aR3 antibody. A: 5a-reductase-3 mRNA expression level in LNCaP, C4-2, LAPC-4, and CWR-R1 cells. 5a-reductase-3 mRNA expression levels in the $\mathrm{CaP}$ cell lines were normalized to the level of expression of 5a-reductase- 3 in the PWR-1E benign prostate epithelial cell line (discontinuous red line). B: PWR-1E, LNCaP, C4-2, LAPC-4, CWR-R1, and CHO-K1 protein lysates (50 $\mu \mathrm{g})$ were immunoblotted and 5areductase-3 protein expression was detected using the RPCI-5aR3 antibody. C: CWR-R1 lysates $(50 \mu \mathrm{g})$ were immunoblotted and $5 \mathrm{a}$-reductase- 3 protein expression was analyzed using RPCI-5aR3 antibody at a concentration of $1 \mu \mathrm{g} / \mathrm{ml}$ or SRD5A3 (Sigma) antibody at concentrations $1 \mu \mathrm{g} / \mathrm{ml}$ and $5 \mu \mathrm{g} / \mathrm{ml}$. D: Immunostaining analyses were performed in CWRR1 using the RPCI-5aR3 antibody. Preincubation of the RPCI-5aR3 antibody with the inhibitor peptide ( 1 and $10 \mu \mathrm{g} / \mathrm{ml}$ ) confirmed specificity. Absence of primary antibody provided negative control (Control). 


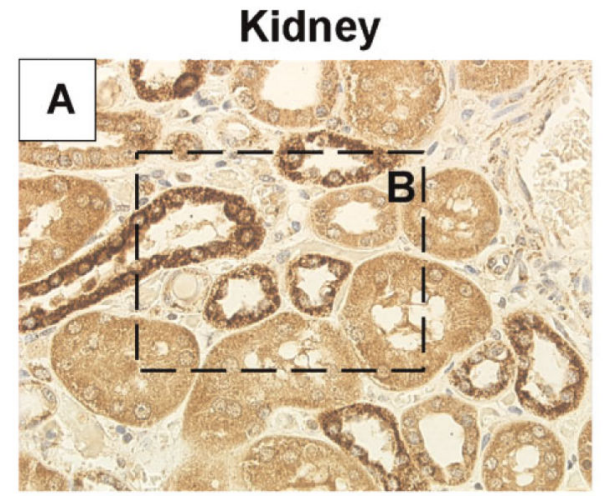

Myometrium

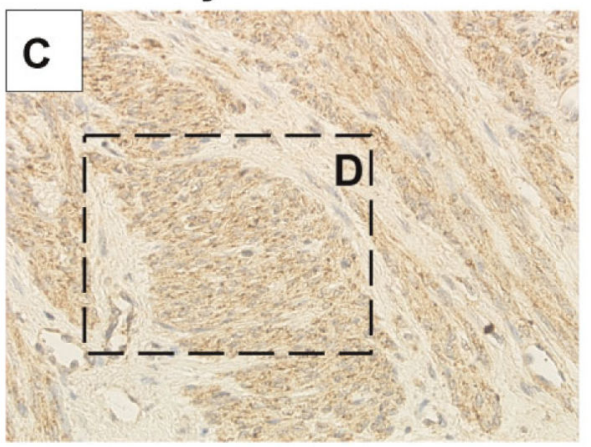

Pancreas

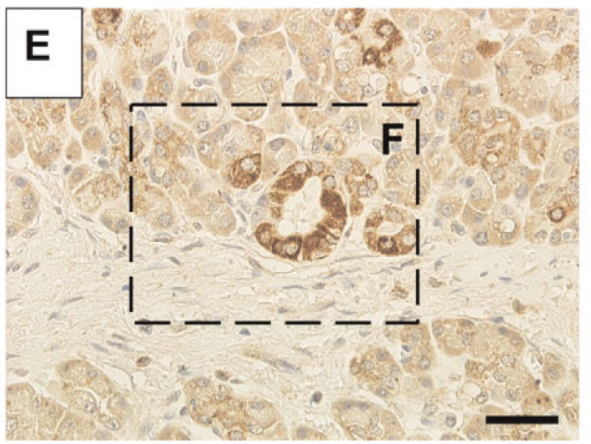

Kidney

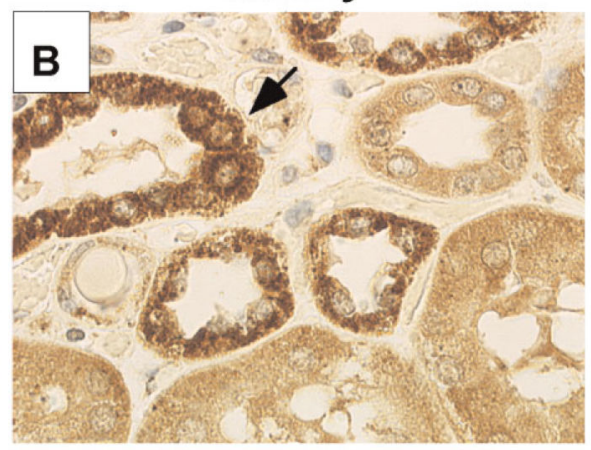

Myometrium

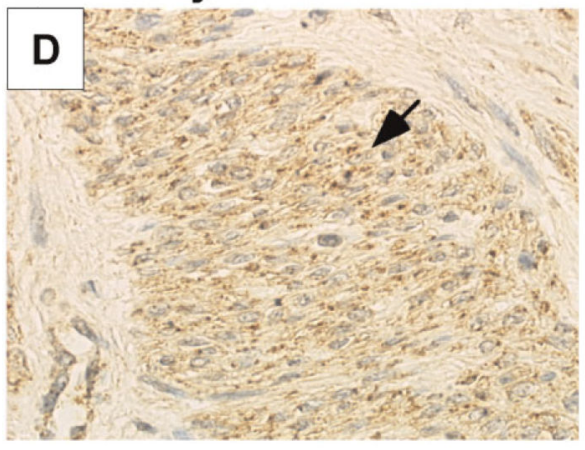

Pancreas

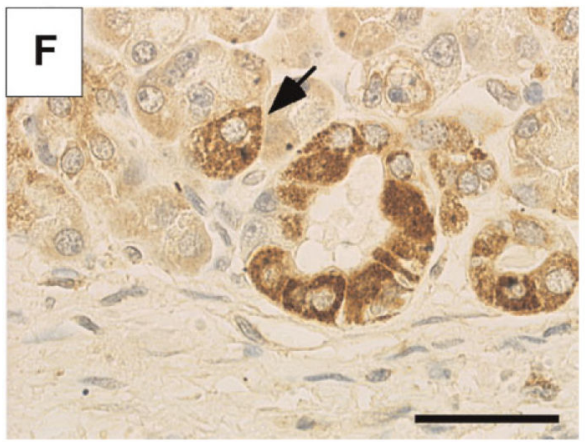

Fig. 2.

5a-reductase-3 immunostaining in benign human tissues. High level expressing tissues (representative sections that demonstrate semi-quantitative data in Table I). In kidney A,B: 5a-reductase-3 expression was localized to the cytoplasm of the epithelial cells from some of the proximal and distal convoluted tubules (B, arrow). In myometrium C,D: $5 a-$ reductase-3 immunostaining was located preferentially to the cytoplasm of the smooth muscle cells (D: arrow, fibers in transverse). In pancreas E,F: 5 a-reductase-3 immunostaining was observed in some of the secretory cells from the acini (F, arrow). Bars: $30 \mu \mathrm{m}$. 
Testis

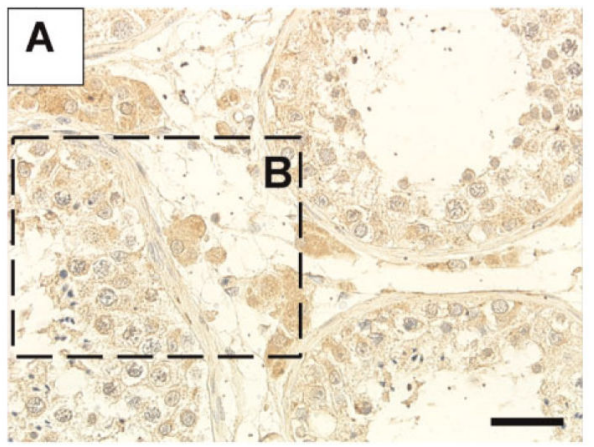

Brain

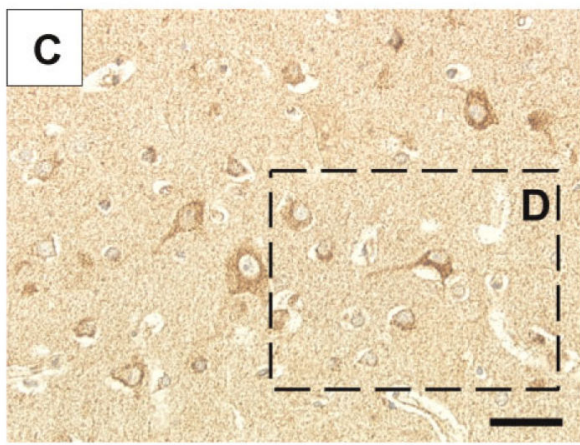

Endometrium

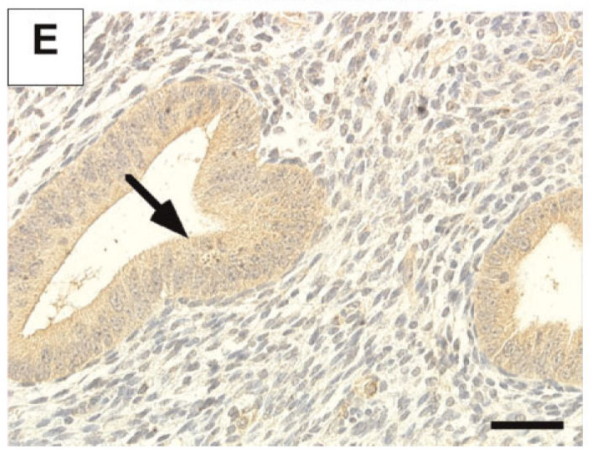

Testis

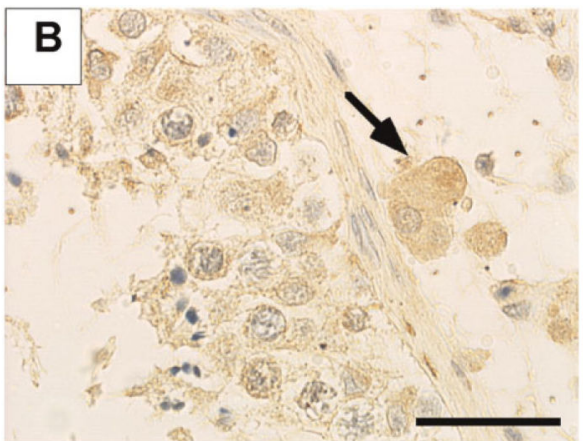

Brain

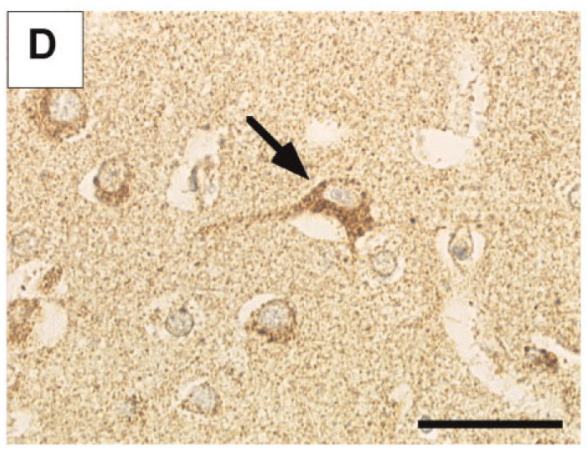

Tonsil

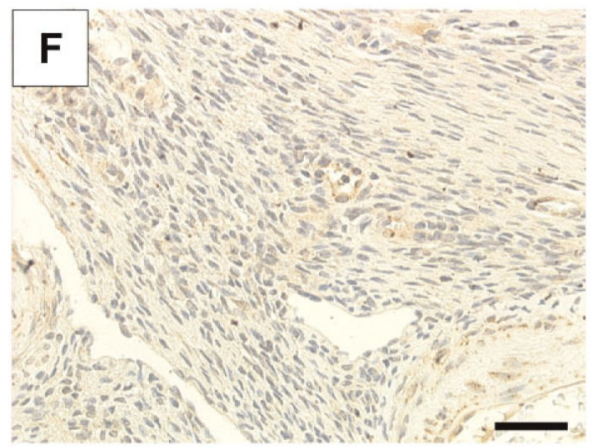

Fig. 3.

5a-reductase-3 immunostaining in benign human tissues. Moderate to low level expressing tissues (representative sections that demonstrate semi-quantitative data in Table I). In testes A,B: 5 a-reductase-3 expression was localized to the cytoplasm of Leydig cells (B, arrow). In brain $\mathbf{C}$ : 5 a-reductase-3 immunostaining was localized to the cytoplasm of neurons (D, arrow). Low levels of 5a-reductase-3 immunostaining were observed in the glandular epithelium of endometrium (E, arrow). 5a-reductase-3 was immunohistochemically undetectable in tonsil (F). Bars: $30 \mu \mathrm{m}$. 


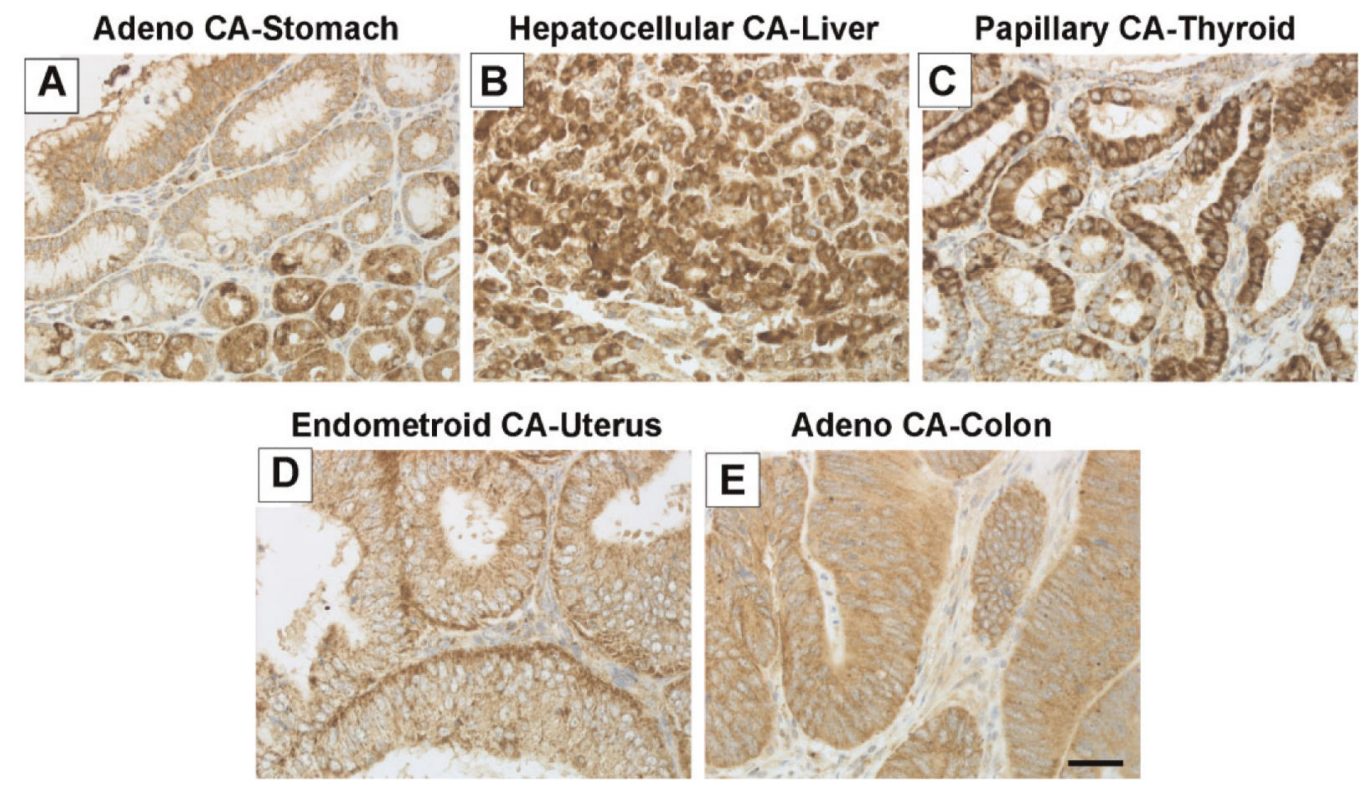

Fig. 4.

5a-reductase-3 immunostaining in malignant human tissues. High level expressing tissues (representative sections that demonstrate semi-quantitative data in Table II). 5a-reductase-3 expression was localized mainly to the cytoplasm of the malignant epithelial cells from adenocarcinoma of the stomach (A), hepatocellular carcinoma of the liver (B), papillary carcinoma of the thyroid $(\mathbf{C})$, endometroid adenocarcinoma of the uterus (D), and adenocarcinoma of the colon (E). Bar: $30 \mu \mathrm{m}$. 


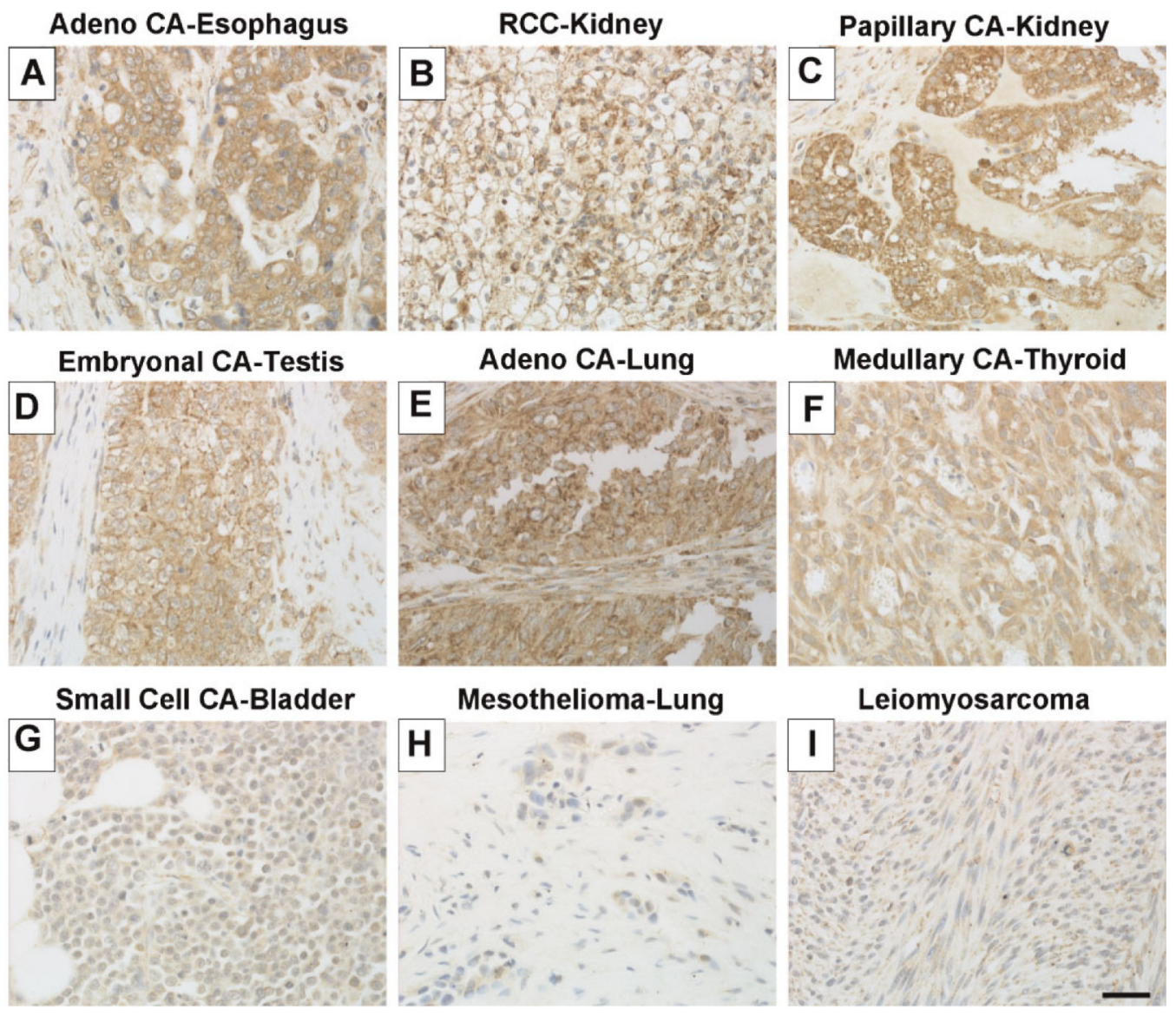

Fig. 5.

5a-reductase-3 immunostaining in malignant human tissues. Moderate to low level expressing tissues (representative sections that demonstrate semi-quantitative data in Table II). Moderate to low levels of 5a-reductase-3 expression were observed in the cytoplasm of neoplastic epithelial cells from adenocarcinoma of the esophagus (A), clear cell renal cell carcinoma of the kidney $(\mathbf{B})$, papillary carcinoma of the kidney $(\mathbf{C})$, embryonal testicular carcinoma (D), adenocarcinoma of the lung (E), and medullary carcinoma of the thyroid $(\mathbf{F})$. Negative 5a-reductase-3 immunostaining was observed in small cell carcinoma of the bladder (G), mesothelioma $(\mathbf{H})$, and leiomyosarcoma (I). Bar: $30 \mu \mathrm{m}$. 


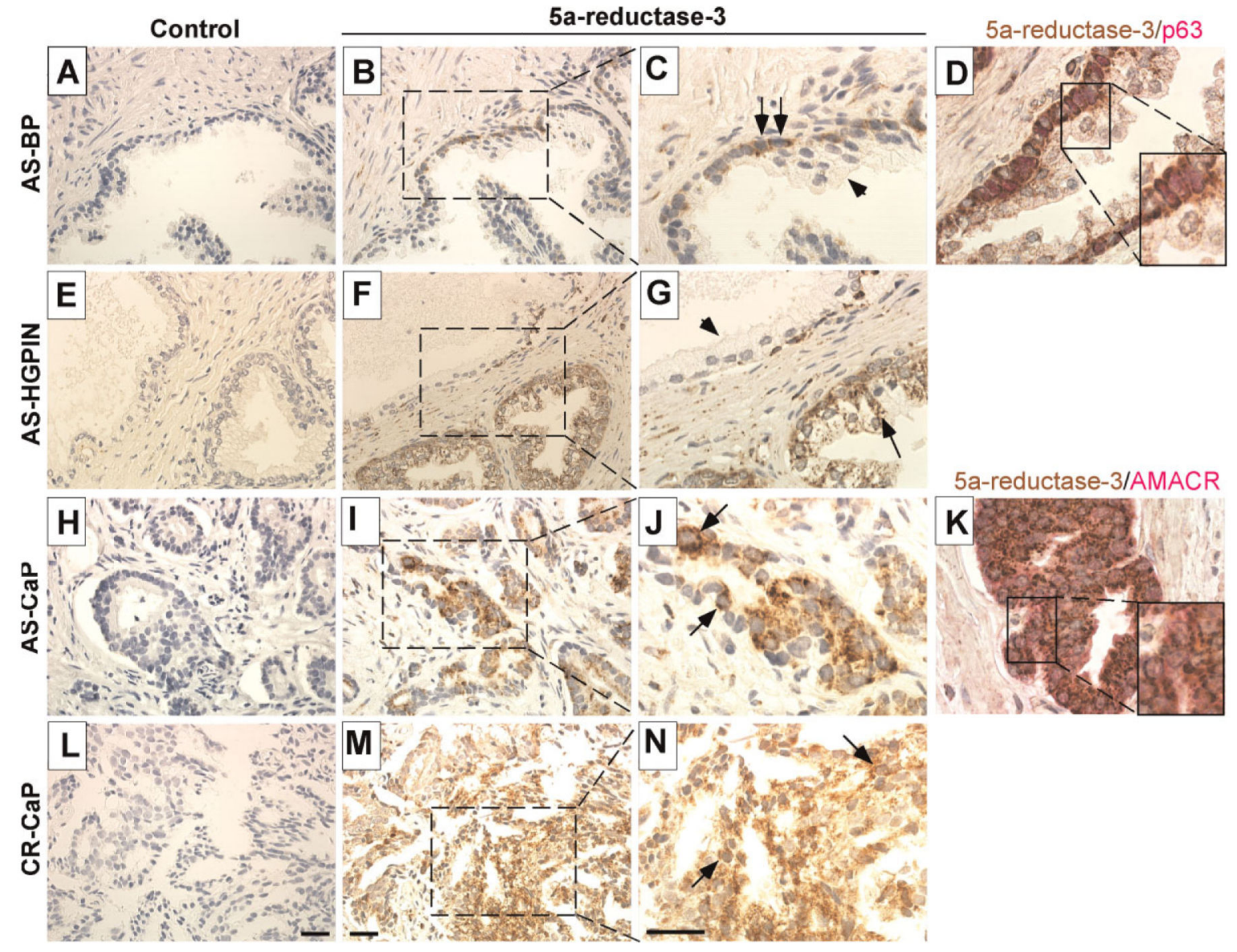

Fig. 6.

5a-reductase-3 immunostaining in androgen-stimulated benign prostate (AS-BP), androgenstimulated high grade intraepithelial neoplasia (AS-HGPIN), androgen-stimulated CaP (AS$\mathrm{CaP})$, and castration-recurrent $\mathrm{CaP}(\mathrm{CR}-\mathrm{CaP})$ tissue sections (representative sections that demonstrate quantitative data in Table III). 5a-reductase-3 immunostaining in AS-BP was observed primarily at the periphery of benign glands, which suggests $5 \mathrm{a}$-reductase- 3 expression in the basal cell compartment (B, $\mathrm{C}$ [arrows]) that was confirmed by colocalization of 5a-reductase-3 (brown cytoplasmic stain) and p63 (rednuclear stain) immunostaining (D). No to low levels of 5a-reductase-3 immunostaining were observed in benign luminal epithelial cells (B [arrowhead]). In HGPIN, 5a-reductase-3 immunostaining was located in both basal cells and hyperproliferative malignant luminal epithelial cells $(\mathbf{F}, \mathbf{G}$ [arrow]) but no to low levels of 5a-reductase-3 immunostaining were observed in luminal epithelial cells of adjacent benign glands (F,G [arrowhead]). In AS-CaP and CR-CaP, 5areductase-3 immunostaining was located in most malignant epithelial cells $(\mathbf{I}, \mathbf{J}, \mathbf{N})$. 5areductase-3 immunostaining was mostly perinuclear when intense (J,N [arrows]. 5areductase-3 immunostaining in malignant epithelial cells was confirmed by co-localization of 5a-reductase-3 (brown cytoplasmic stain) and AMACR (red cytoplasmic stain) immunostaining (K). Incubation in the absence of primary antibody provided negative 
controls (A,E,H,L). Black bars: $30 \mu \mathrm{M}$. Images reduced from 200× magnification (columns 1 and 2) or 400× magnification (columns 3 and 4). 
TABLE I

5a-Reductase-3 Immunostaining in Benign Human Tissues

\begin{tabular}{lccl}
\hline Tissue & $\begin{array}{c}\text { Number of positive cases/ } \\
\text { total cases }\end{array}$ & $\begin{array}{c}\text { Staining } \\
\text { intensity }\end{array}$ & \multicolumn{1}{c}{ Preferential localization } \\
\hline Brain & $6 / 20$ & $-/+$ & Neurons \\
Breast & $4 / 20$ & $-/+$ & Myoepithelial cells \\
Colon & $7 / 20$ & $-/+$ & Epithelial cells from colonic glands \\
Endometrium & $10 / 20$ & $-/+$ & Glandular epithelium \\
Kidney & $20 / 20$ & +++ & Epithelial cells (PCT, DCT) \\
Liver & $20 / 20$ & +++ & Hepatocytes \\
Lung & $2 / 20$ & $-/+$ & Bronchial epithelium \\
Myometrium & $11 / 20$ & ++ & Smooth muscle cells \\
Ovary & $0 / 20$ & - & \\
Pancreas & $15 / 15$ & $++/+++$ & Secretory cells (GA) \\
Prostate & $23 / 25$ & ++ & Basal cells \\
Skeletal muscle & $2 / 2$ & $+/+$ & Skeletal muscle cells \\
Skin & $1 / 1$ & $+/++$ & Stratum basale, stratum spinosum \\
Spleen & $0 / 20$ & - & \\
Stomach & $12 / 20$ & $+/++$ & Epithelial cells from the base of the gastric glands \\
Testes & $8 / 20$ & $-/+$ & Leydig cells \\
Thyroid & $13 / 20$ & $-/+$ & Cuboidal epithelium from thyroid follicles \\
Tonsil & $0 / 15$ & - & \\
\hline
\end{tabular}

Criteria for immunohistochemical analysis: -, negative staining; +, weak staining; ++, moderate staining; +++, intense staining; PCT, proximal convoluted tubule; DCT, distal convoluted tubule; GA, glandular acini. 
TABLE II

5a-Reductase-3 Immunostaining in Malignant Human Tissues

\begin{tabular}{|c|c|c|}
\hline Tissue & $\begin{array}{l}\text { Number of } \\
\text { positive cases/ } \\
\text { total cases }\end{array}$ & $\begin{array}{l}\text { Staining } \\
\text { intensity }\end{array}$ \\
\hline Adrenal Pheochromocytoma & $1 / 2$ & $-1+$ \\
\hline \multicolumn{3}{|l|}{ Bladder } \\
\hline Low grade TCC & $0 / 2$ & - \\
\hline High grade TCC & $2 / 2$ & + \\
\hline Small Cell CA & $2 / 2$ & - \\
\hline \multicolumn{3}{|l|}{ Breast } \\
\hline Lobular CA & $2 / 2$ & + \\
\hline Metaplastic CA & $2 / 2$ & + \\
\hline Colon Adeno CA & $2 / 2$ & ++ \\
\hline Esophagus Adeno CA & $2 / 2$ & $+/++$ \\
\hline \multicolumn{3}{|l|}{ Kidney } \\
\hline Chromophobe CA & $4 / 4$ & +++ \\
\hline Papillary CA & $1 / 2$ & ++ \\
\hline Renal Clear Cell CA & $2 / 2$ & ++ \\
\hline Liver HCC & $2 / 2$ & $++/+++$ \\
\hline \multicolumn{3}{|l|}{ Lung } \\
\hline Adeno CA & $2 / 2$ & ++ \\
\hline Mesothelioma & $2 / 2$ & - \\
\hline Leiomyosarcoma & $2 / 2$ & - \\
\hline \multicolumn{3}{|l|}{ Ovary } \\
\hline Mucinous CA & $4 / 4$ & $+/++$ \\
\hline Serous CA & $0 / 2$ & - \\
\hline Stomach Adeno CA & $2 / 2$ & $++/+++$ \\
\hline \multicolumn{3}{|l|}{ Testis } \\
\hline Seminoma & $2 / 2$ & ++ \\
\hline Embryonal CA & $2 / 2$ & + \\
\hline Yolk Sac CA & $1 / 2$ & ++ \\
\hline \multicolumn{3}{|l|}{ Thyroid } \\
\hline Papillary CA & $4 / 4$ & +++ \\
\hline Medullary CA & $2 / 2$ & + \\
\hline Uterus Endometroid CA & $2 / 2$ & ++ \\
\hline
\end{tabular}

Criteria for immunohistochemical analysis: -, negative staining; +, weak staining; ++, moderate staining; +++, intense staining; TCC, transitional cell carcinoma; CA, carcinoma; HCC, hepatocellular carcinoma. 


\section{TABLE III}

5a-Reductase-3 Immunostaining of AS-BP, AS-CaP, and CR-CaP

\begin{tabular}{lccc}
\hline & \multicolumn{3}{c}{ Mean \pm SE } \\
\cline { 2 - 4 } & AS-BP & AS-CaP & CR-CaP \\
\hline Visual score & & & \\
$\quad$ Nuclear & $14.7 \pm 4.4$ & $25.6 \pm 3.5$ & $29.2 \pm 8.4$ \\
Cytoplasmic & $115.6 \pm 10.5$ & $200.5 \pm 9.1^{a}$ & $163 \pm 11.7^{a}$ \\
MOD & & & \\
Cytoplasmic & $0.32 \pm 0.02$ & $0.50 \pm 0.03^{a}$ & $0.49 \pm 0.03^{a}$ \\
\hline
\end{tabular}

AS-BP, androgen-stimulated BP; AS-CaP, androgen-stimulated CaP; CR-CaP, castration-recurrent CaP; SE, standard error.

${ }^{a}$ Statistically different than androgen-stimulated BP. 